DE GRUYTER DOI: $10.2478 / \mathrm{v} 10129-011-0055-5$

Magdalena Gut ${ }^{1}$, Przemysław Szecówka ${ }^{1}$, Andrzej Bichoński ${ }^{2}$

${ }^{1}$ Grain Plants Institute of Plant Breeding and Acclimatization Institute - National Research Institute in Cracow, ${ }^{2}$ Polanowice Plant Cultivation Station

\title{
SELECTED TRAITS OF SPRING WHEAT IN POLISH CLIMATIC CONDITIONS
}

\author{
PART 1. THE TRAITS OF YIELD COMPONENTS AND BASIC
} TECHNOLOGICAL PARAMETERS

\begin{abstract}
The purpose of the paper was to determine phenotype and genotype variability of yield components structure (number of grains, grain mass and 1000 grain weigh) as well as of the basic technological traits (sedimentation number, falling number, protein percentage content per grain). The research also considered the issue of pre-harvest sprouting. During each vegetation season rainfall and temperature were recorded. The examined material were the strains of $\mathrm{F}_{6}-\mathrm{F}_{7}$ generation. Coefficients of correlation between the values of particular traits and mean temperatures and rainfall sum during a given season showed that yield component parameters were significantly modified by temperature; whilst warm vegetation seasons proved to be beneficial. Negative correlation between the rainfall sum and the number of grains and grain mass as well as 1000 grain weight suggests that the excess of water may be more detrimental for the yield than its shortage. Coefficients of correlation between the values of basic technological parameters and mean temperature were negative and not very high or low or even - insignificant, as in the case of falling number. High $\mathrm{h}^{2}$ coefficients suggest a good heritability of yield components parameters, and yield per ear seem to be the trait that was transmitted best. Amongst the basic quality indicators, the highest heritability was observed in the case of falling number and the lowest one in the case of sedimentation number. The weakest genetic conditioning was observed in the case of resistance to sprouting, measured as the percentage of sprouting grains in the ear. It seems therefore that genetic variability was, to a large degree, masked by the environmental impact and, in spite of a high degree of genetic conditioning, the effectiveness of selection based on a visual evaluation of the forms rated for further cultivation might be limited.
\end{abstract}

Key words: climate, quality of wheat, wheat

Communicated by Henryk J. Czembor 


\section{INTRODUCTION}

Demographic prognoses and economic conditions pose many challenges for agriculture, and, whereas in developing countries they concern mostly the quantity of the food produced, in the countries more economically developed, this problem concerns mostly its quality.

The profitability of cultivation is conditioned by so-called end-use quality of the grain obtained corresponding to the requirements of food industry. Meeting these requirements may be imepeded by weather anomalies ascribed to climatic changes. From computer simulations for Australia, it is seems that with regards to wheat, the waste in yield caused by global warming is estimated to be $29 \%$ (Anwar et al. 2007). Environmental impact on yield, and grain quality of wheat is also clearly observed in the region of the Mediterranean Sea (Asseng et al. 2008, Schillinger et al. 2008), where the basic problem is posed by the limitations in water availability. The research carried out by Chloupek et al.(2004) shows that although in European countries with moderate climate, these changes have a fairly mild progress with the observed increase of temperature, amounting in the last decade to $0.087{ }^{\circ} \mathrm{C} /$ year, proving to be beneficial for many cultivations, including cereals. It seems however, that the above-named authors fail to devote enough attention to the issue of water shortage. The research of winter wheat (Gut, Bichoński 2007) and barley (Gut et al. 2004) showed that in Poland, some periodic droughts are quite frequent phenomena having a significant influence on cereal quality parameters. It seems therefore necessary for the genotypes planned for the introduction into cultivation to have large adaptation abilities, giving high grain yield with high quality parameters, irrespectively of the weather conditions. Obtaining such forms, however, poses some serious difficulties. One of the causes of such a situation may be the fact that both "yield" and "quality" are generally defined as complex traits and thus they are treated collectively, although specific elements of this complex should rather be analysed and examined. It must also be remembered that both yield enhancing traits and those constituting its high value indicate a strong interaction between the genotype and environment and the strongest effects are observed with regard to the level and distribution of rainfall and temperatures (Dupont and Altenbach 2003, Gooding et al. 2003)

The purpose of the paper was to determine phenotype and genotype variability of yield components structure (number of grains, grain mass and 1000 grain weight), as well as of the basic technological traits (sedimentation number, falling number, protein percentage content per grain). The research took also into consideration pre-harvest sprouting, because this is the first criterion of grain evaluation. The results of the research were analysed in the context of meteorological data (rainfall, tem- 
perature) in order to determine the degree in which the examined traits and correlations between them were changing under the influence of weather.

\section{MATERIALS AND METHODS}

The examined material were the strains of $\mathrm{F}_{6}-\mathrm{F}_{7}$ generation cultivated in Kończewice Plant Breeding and Acclimatization Institute (currently Strzelce Plant Breeding, Sp. z o.o) In 2007-2009, these strains grew in the Grain Plants Institute of Plant Breeding and Acclimatization Institute in Cracow on fields with the square area of $1 \mathrm{~m}^{2}$, with a standard level of fertilisation. In the phase of full maturity, samples of $3 \times 3$ ears were collected from each field in order to determine their resistance to sprouting; moreover 50 ears were collected for each field, as well, in order to determine yield the following component parameters: grain number and mass per ear and 1000 grains weight. Resistance to sprouting was determined in full maturity, by means of evaluating the sprout visible in cut ears, defined as the per cent of sprouted grains compared to the total number of grains per sample (Gut 2003). Sedimentation number, falling number, protein content were determined in accordance with the methodology described by $\mathrm{Cy}-$ gankiewicz (2000). During the entire vegetation period, the amount of rainfall and temperature were recorded with the use of a portable meteorological station - Wetterstation, Model WS 3600.

The results obtained were statistically processed (variance analysis, summary statistics, correlations) in Statistica 8.0 software. Moreover, general variability, phenotype and genotype as well as genotype conditioning coefficients were calculated, similarly as in the case of research of winter wheat (Gut, Bichoński 2007 and publications quoted therein).

\section{RESULTS AND DISCUSSION}

Both mean values and variability scopes of the examined traits differed in individual years (Table1). Analysis of variance (Table2) in single classification indicated a significant influence of the given year of research on the values of all examined traits; whereas Duncan test carried out (unpublished data) showed that the differences between the years: 2007, 2008, 2009 were significant both for yield competent parameters and basic technological traits. In the case of sprouting defined as a percent of sprouted grains in the cut artificially hydrated ears, significant differences were observed only between 2008 and 2009. The year 2008 was the most beneficial for yield component parameters. Among technological parameters, falling number was the trait that was changing the most and the protein content was the one changing the least. The largest variability was observed in the case of resistance to sprouting, and in 2008 the examined objects sprouted the most with differences in the resistance of particular 
strains being especially distinct (variability scope from 0 to $95 \%$ of the visible sprout). From the research of Biddulph et al. (2008) as well as earlier research on wheat and barley (Gut et al. 2004, Gut, Bichoński 2007) it stems that temperature and rainfall have a decisive influence on the creation of both yield components parameters and quality traits. That is why, the authors of this paper concentrate on these two elements. In the course of the experiments, the distribution of rainfall and temperatures were analysed in much detail, however in order to clarify the image and facilitate the comparison, the weather graphs concerning particular years (Fig.1 and 2) show the data for given months in the sowing to harvest.

Table 1

Mean values, ranges and variation coefficients of the examined traits in 2007-2009

\begin{tabular}{|c|c|c|c|c|}
\hline \multirow{2}{*}{ Traits } & & \multicolumn{3}{|c|}{ Years } \\
\hline & & 2007 & 2008 & 2009 \\
\hline \multirow{2}{*}{ Number of grains pe } & mean & 29.8 & 43.1 & 38.8 \\
\hline & range & $21.8-37.7$ & $28.0-54.0$ & $31.0-53.3$ \\
\hline \multirow{2}{*}{ Grain mass per ear } & mean & 0.8 & 1.8 & 1.4 \\
\hline & range & $0.5-1.1$ & $1.3-2.3$ & $1.1-1.7$ \\
\hline \multirow{2}{*}{1000 grains weight } & mean & 27.9 & 40.8 & 36.1 \\
\hline & range & $21.1-36.3$ & $34.0-53.7$ & $29.0-44.3$ \\
\hline \multirow{2}{*}{ Sedimentation numb } & mean & 86.6 & 73.5 & 80.7 \\
\hline & range & $64.0-96.0$ & $51.0-84.5$ & $58.0-88.0$ \\
\hline \multirow{2}{*}{ Falling number } & mean & 397.3 & 193.9 & 348.0 \\
\hline & range & $190-492$ & $62-357$ & $187-447$ \\
\hline \multirow{2}{*}{$\%$ protein content in } & mean & 14.5 & 12.9 & 13.5 \\
\hline & range & $12.7-16.3$ & $11.6-14.3$ & $12.3-15.1$ \\
\hline \multirow{2}{*}{ Sprouting } & mean & 7.1 & 35.7 & 3.8 \\
\hline & range & $0-36.0$ & $0-95.5$ & $0-29.7$ \\
\hline
\end{tabular}

With the assumption that in the case of wheat, the rainfall level of $400 \mathrm{~mm}$ during the season guarantees a satisfactory supply of crops with water, whilst the level $300 \mathrm{~mm}$ means that there is water deficit (Uddin et al. 1992), it may be stated that the year 2009 with the rainfall sum in the vegetation period amounting $423 \mathrm{~mm}$ was the most beneficial. The year 2007 was characterised by a slight shortage of water (378 $\mathrm{mm}$ rainfall/season). A distinct water deficit was observed in 2008, when only $268 \mathrm{~mm}$ rain fell during the entire season with a detrimental rainfall distribution as well (Fig.1). 


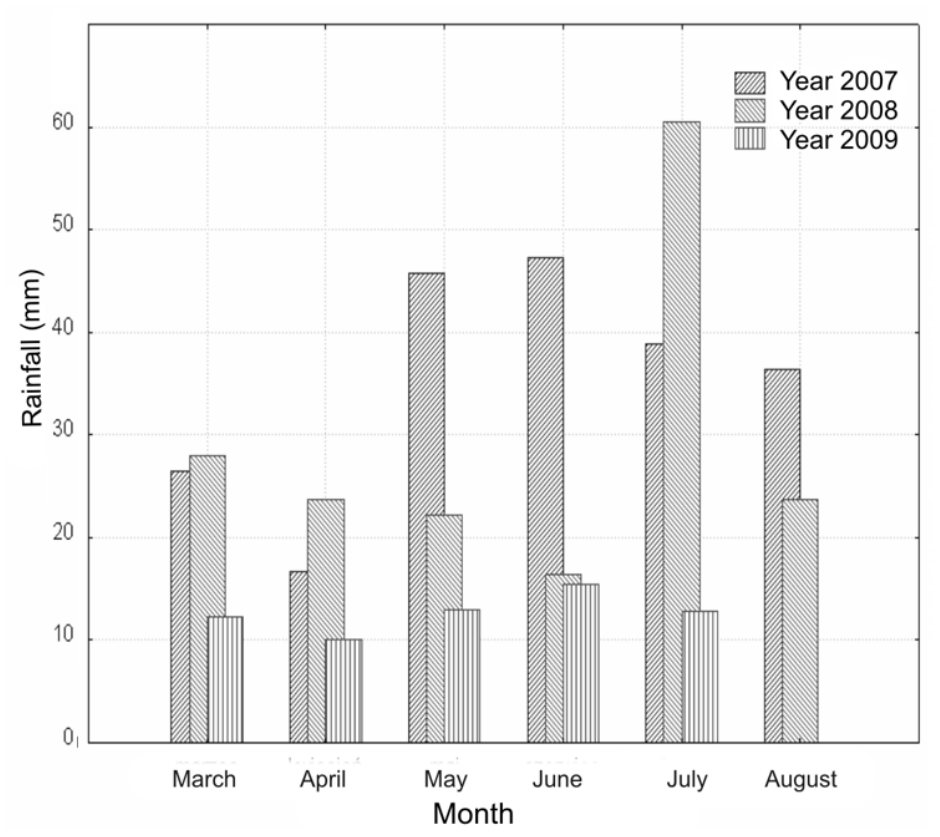

Fig.1. Monthly sums of rainfall in 2007-2009

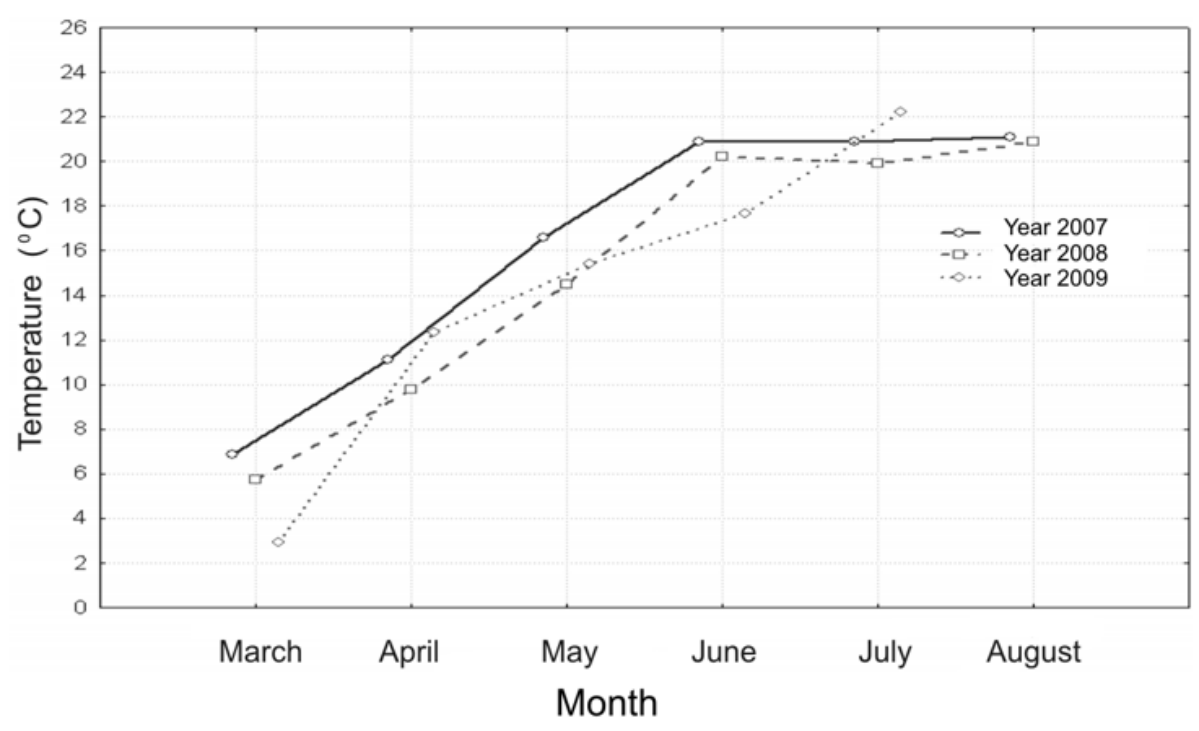

Fig. 2. Mean monthly temperatures in 2007-2009

At the beginning of the vegetation season (April, May) there were longer periods without rain, whilst high sums of rainfall were observed in the period of grain maturation. Monthly mean temperatures in 2007 and 2009, had a similar course, with 
2007 being slightly warmer. In 2008, the distribution of mean monthly temperatures significantly differed from other years in comparison. The comparison of meteorological data (Fig.1. and 2) with mean values of yield components parameters seem to allow for questioning the assumption concerning an optimal level of irrigation for wheat made by Uddin (1992), which is the one generally accepted. On the other hand, however, the fact that must be taken into consideration is that in the case of yield measured with the grain mass per unit of land, a decisive factor proves to be the number of grains $/ \mathrm{m}^{2}$ (Fischer 2008), which was not examined in this research.

One-factor analysis of the variations of the examined traits

Table2

\begin{tabular}{|c|c|c|c|c|c|c|c|c|}
\hline \multirow{2}{*}{$\begin{array}{l}\text { Variability } \\
\text { Sprouting }\end{array}$} & \multicolumn{3}{|c|}{ Between groups } & \multicolumn{3}{|c|}{ Within groups } & \multirow{2}{*}{$\begin{array}{c}\begin{array}{c}\text { Test } F \\
\text { values }\end{array} \\
36.447\end{array}$} & \multirow{2}{*}{$\begin{array}{c}\begin{array}{c}\text { Probability } \\
\text { level }\end{array} \\
0.000 *\end{array}$} \\
\hline & 22210 & 2 & 11105.0 & 44789.4 & 147 & 304.690 & & \\
\hline No of grains per ear & 4751 & 2 & 2375.6 & 2946.3 & 147 & 20.043 & 118.525 & $0.000 *$ \\
\hline Grain mass per ear & 22 & 2 & 11.0 & 4.4 & 147 & 0.030 & 367.892 & $0.000 *$ \\
\hline 1000 grains weight & 4249 & 2 & 2124.6 & 2014.2 & 147 & 13.702 & 155.062 & $0.000 *$ \\
\hline Sedimentation no & 4205 & 2 & 2102.5 & 8566.5 & 146 & 58.675 & 35.833 & $0.000 *$ \\
\hline Falling number & $1 \mathrm{E}+06$ & 2 & 555867.7 & 675065.0 & 146 & 4623.733 & 120.221 & $0.000 *$ \\
\hline $\begin{array}{l}\% \text { protein in dry } \\
\text { mass }\end{array}$ & 47 & 2 & 23.4 & 47.6 & 146 & 0.326 & 71.982 & $0.000 *$ \\
\hline
\end{tabular}

*-significant on the level of $\alpha=0.05$

Coefficients of correlation between mean temperature and the sum of rainfall in the vegetation season and the examined traits

\begin{tabular}{lll}
\hline \multicolumn{1}{c}{ Traits } & Mean temperature & Rainfall sum \\
\hline Number of grains per ear & $0.72^{*}$ & $-0.42^{*}$ \\
Yield per ear & $0.81^{*}$ & $-0.44^{*}$ \\
TGW & $0.74^{*}$ & $-0.43^{*}$ \\
Sedimentation number (SDS) & $-0.45^{*}$ & $0.17^{*}$ \\
Falling number & $-0.50^{*}$ & 0.08 \\
$\%$ protein in dry mass & $-0.63^{*}$ & $0.37 *$ \\
$\%$ sprouting & $0.42 *$ & $-0.27 *$ \\
\hline
\end{tabular}

*-significant on the level of $\alpha=0.05$

It must not be therefore excluded that in the case of lack of water, the decrease of tillering modifies high values of the yield components structure. 
The correlations between the values of individual traits and mean temperatures and rainfall sum during the season (Table3) have shown that the parameters of the yield components structure were significantly modified by the temperature, with warm vegetation seasons being favourable. The influence of rainfall, though significant, proved to be weaker.

A negative correlation between the rainfall sum and the grain number and grain mass per ear, as well as 1000 grains weight suggest that in the case of spring wheat, similarly as in the case of spring barley (Gut et al.2004) the excess of water may prove to be more adverse for the yield than its lack. This suspicion is confirmed by high mean values of these traits observed in 2008 (Table1).

In the case of basic technological parameters, the situation is opposite. The correlation coefficients of the examined traits with mean temperature are negative and not very high, and with rainfall sum - positive, low or even - as in the case of falling number - insignificant.

Sprouting in ears, in a significant way, however not very high $(\mathrm{r}=0.42)$ increases in a higher temperature, whereas a higher sum of rainfall has an inhibiting influence on this process. Perhaps this could be the result of the increase of the activity of alpha-amylase, which may be suggested by a negative correlation between temperature and falling number. To explanation this phenomenon, however, some additional research would be required, and this could reach beyond the scope of this work.

The above named significant differentiation of the examined forms (Table2) allowed to calculate the general variability coefficient $(\mathrm{CV})$, phenotype variability coefficient $\left(\mathrm{CV}_{\mathrm{p}}\right)$, genotype variability coefficient $\left(\mathrm{CV}_{\mathrm{g}}\right)$, as well as genetic conditioning $(\mathrm{H})$ as presented in Table 4.

The coefficients of general variability $(C V)$, phenotype variability $\left(C_{p}\right)$, genotype variability $\left(C V_{g}\right)$, as well as genetic conditioning $\left(h^{2}\right)$ concerning the examined traits

\begin{tabular}{lcccc}
\hline \multirow{2}{*}{ Trait } & \multicolumn{4}{c}{ Coefficient } \\
\cline { 2 - 4 } & $\mathrm{H}$ & $\mathrm{CV}[\%]$ & $\mathrm{Cv}_{\mathrm{g}}[\%]$ & $\mathrm{Cv}_{\mathrm{p}}[\%]$ \\
\hline Number of grains per ear & 0.50 & 10.52 & 6.12 & 8.62 \\
Yield per ear & 0.28 & 12.38 & 4.49 & 8.44 \\
TGW & 0.61 & 8.72 & 6.34 & 8.10 \\
Sedimentation number (SDS) & 0.87 & 5.46 & 8.09 & 98.00 \\
Falling number & 054 & 18.85 & 11.69 & 2.05 \\
\% protein in dry mass & 0.64 & 2.13 & 1.63 & 14.31 \\
Sprouting & 0.32 & 8.44 & 8.06 & \\
\hline
\end{tabular}

High values of coefficient $\mathrm{H}$ indicate a good heritability of the number of grains per ear and the 1000 grains weight, however, the heritability of yield 
per ear seems to be quite low. Among basic quality indicators, sedimentation number had the highest coefficient of genetic conditioning. Resistance to sprouting, measured as the number of sprouting grains in an ear, appeared to be weakly genetically determined. The comparison between the coefficients of genotype and phenotype variability shows a significant influence of environment on all the examined traits. It seems therefore that the genotype variability is here significantly masked by the environmental impact, which might decrease the efficiency of the selection based on visual evaluation of the forms typed for further cultivation. In the light of the data presented so far, it seems also that obtaining the forms resistant to sprouting would pose the biggest problem. This trait has both a low $\mathrm{H}$ coefficient and the highest phenotype variability. Therefore, a statement may be risked that the above described phenomenon is a basic cause of the difficulties in obtaining productive, quality forms resistant to sprouting, and the solution for the problem could be found in the selection based on the markers of the beneficial traits, independent from the environmental factors.

The necessity to combine a complex of utility traits within one genotype results in the fact that not only the determination of genetic variability and conditioning, but also of the correlations between the examined traits seem to be especially significant for cultivation. Some earlier research of winter wheat (Gut, Bichoński 2007) proved that the weather factors may also influence the correlations between the analysed quality parameters. It seemed therefore interesting to verify whether a similar phenomenon occurs in the case of spring wheat and, if so, in what degree. The correlation coefficients calculated in particular years of research (data not published in this paper) were generally not significant or the degree of their significance, or its presence or lack changed within particular years. With regards to the permanent set of genotypes and the place of research, the causes for this phenomenon may be found in the influence of climactic factors, whilst the data presented in table 3 suggest that the effect of their influence on particular traits was varied.

The coefficients of phenotype correlation calculated after the results of the experiments were averaged, thus after the environmental variability effect was eliminated, gave a totally different picture (Table 5.) The correlations between all the examined traits proved to be significant although the coefficients of correlations were not too high. The coefficients of correlation between the yield component parameters seem to be obvious and, as such, they do not require any further discussion. What needs to be observed, however, are the negative coefficients of correlation between basic technological parameters and yield components structure parameters, seen only after the results of the three-years' experiments are averaged. 
Table 5

The coefficients of correlation between the mean values of the analysed traits

\begin{tabular}{|c|c|c|c|c|c|c|}
\hline Traits & Sprouting & $\begin{array}{c}\text { Number of } \\
\text { grains per } \\
\text { ear }\end{array}$ & $\begin{array}{l}\text { Yield per } \\
\text { ear }\end{array}$ & $\begin{array}{c}1000 \text { grains } \\
\text { weight }\end{array}$ & $\begin{array}{l}\text { Sedimen- } \\
\text { tation } \\
\text { number } \\
\text { (SDS) }\end{array}$ & $\begin{array}{l}\text { Falling } \\
\text { number }\end{array}$ \\
\hline \multicolumn{7}{|l|}{ Sprouting } \\
\hline Number of grains per ear & $-0.41^{*}$ & & & & & \\
\hline Yield per ear & $-0.45^{*}$ & $0.89 *$ & & & & \\
\hline 1000 grains weight & $-0.32 *$ & $0.54 *$ & $0.86^{*}$ & & & \\
\hline Sedimentation number (SDS) & $0.42 *$ & $-0.51 *$ & $-0.50 *$ & $-0.33^{*}$ & & \\
\hline Falling number & $0.49 *$ & $-0.53 *$ & $-0.65^{*}$ & $-0.61 *$ & $0.49 *$ & \\
\hline$\%$ protein in dry mass & $0.31 *$ & $-0.58 *$ & $-0.63 *$ & $-0.54 *$ & $0.63 *$ & $0.54 *$ \\
\hline
\end{tabular}

*-significant on the level of $\alpha=0.05$

A significant dependence between the falling number and sprouting calculated in cut ears might suggest the usefulness of this indicator in the evaluation of resistance to sprouting; however Mares and Mrva (2008) claim that with regards to late maturity $\alpha$-amylase which is a genetic defect in some wheat cultivars, this indicator might prove misleading.

Probable correlations of this kind, which are difficult to determine in single year and single point experiments might be one of the reasons on obtaining forms combining yield and high technological value. The resistance to sprouting of the genotypes introduced into cultivation correlated negatively with the examined technological traits and positively correlated with yield components structure will most probably constitute a serious difficulty. Another thing which require staking into consideration is the genotype interaction with the method of evaluation of resistance to sprouting. That this why the issue of pre-harvest sprouting was discussed in a separate work, forming the second part of this work.

\section{REFERENCES}

Anwar M.R, O’Leary G., McNeil D., Hossain H., Nelson R., 2007 Climate change impact on rainfed wheat in south-eastern Australia Field Crops Research, 104, (1-3): 139-147

Asseng S., Milroy S.P.,. Poole M.L 2008, Systems analysis of wheat production on low water-holding soils in a Mediterranean-type environment: I. Yield potential and quality Field Crops Research, 105(1-2): 97106 ,

Biddulph T.B., Plummer J.A., Setter T.L., Mares D.J., 2008,Seasonal conditions influence dormancy and preharvest sprouting tolerance of wheat (Triticum aestivum L.) in the field Field Crops Research, 107, (2): 116-128.,

Chloupek O., Hrstkova P., Schweigert P. 2004,Yield and its stability, crop diversity, adaptability and response to climate change, weather and fertilisation over 75 years in the Czech Republic in comparison to some European countries Field Crops Research 85(2-3): 167-190. 
Cygankiewicz A. 2000. Ocena jakościowa polskich odmian pszenicy ozimej i jarej w porównaniu do odmian zagranicznych oraz rodów z doświadczeń wstępnych ze zbioru 1998 roku. Biul IHAR. 214: 31-48

Dupont F. M.,. Altenbach S. B., 2003, Molecular and biochemical impacts of environmental factors on wheat grain development and protein synthesis. Journal of Cereal Science 38(2): 133-146

Fischer R.A. 2008, The importance of grain or kernel number in wheat: A reply to Sinclair and Jamieson Field Crops Research, 105, 1-2, (2) 15-21

Gut M. 2003. Odporność zbóż na porastanie przedżniwne - problemy i perspektywy (Cereal's Resistance to pre-harvest sprouting - problems and perspectives). Biul. IHAR 230: 15-21

Gut M., Bichoński A., Mikulski W., 2004 Influence of water stress on spring barley yields under polish climatic conditions. Acta Agron. Hung. 52(1) 29-36

Gut M., Bichoński A.2007 Technological quality and yield components of winter wheat lines under Polish climatic coditions Cereal Res Comm. 15(1): 151-161

Mares DJ, Mrva K 2008 Late-maturity a-amylase: low falling number in wheat in the absence of preharvest sprouting. J Cereal Sci 47: 6-17

Schillinger W.F., Schofstoll S.E., Alldredge J.R. 2008, Available water and wheat grain yield relations in a Mediterranean climate Field Crops Research, 109(1-3): 45-49

Uddin N., Carver B.F. Clutter A.C. 1992. Genetic analysis and selection for wheat yield in drought stresed and irrigated environments. Euphytica 62: 89-96 